\title{
Czesław Domański*
}

\section{OSKAR RYSZARD LANGE (1904-1965)}

Oskar Ryszard Lange - the economist and national activist - was born on 27 July, 1904 in Tomaszow Mazowiecki as a son of an industrialist.

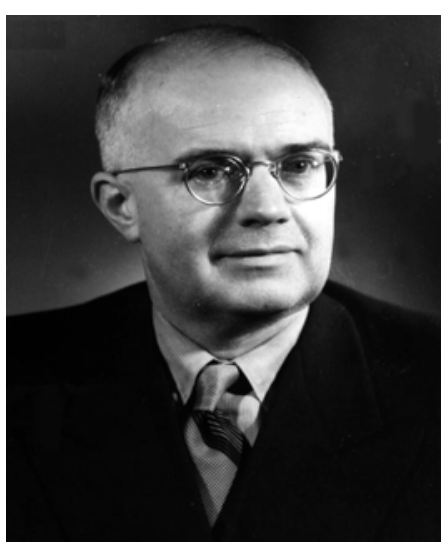

Professor Oskar Ryszard Lange

He started his education in 1912, first at the Lodz Merchant School, and then at the Philology Grammar School in Tomaszow Mazowiecki. In the years 1922-1926 he studied at the Poznan University for one year, followed by two years of study at the Jagiellonian University in Kraków.

In 1928 he submitted a doctoral dissertation entitled : „Economic trends in the economic life of Poland 1924-1927", and in 1931 he wrote the habilitation (post-doctoral) dissertaton on "Statistical reserach on economic trends" at the Jagiellonian University.

For the following years - until 1934 - he held lectures in the theory of statistics, and they subsequently appeared in print as a textbook entitled. „The theory of statistics”.

In the years 1934-1936 Lange stayed in the USA and the United Kingdom as a scholarship-holder and a lecturer. In the second half of 1936 he returned to Kraków to the Department of Statistics. In 1937 he went to California where he was offered the post of a lecturer in economics at the State University. He continued his academic career at the renowned Stanford University. From 1937 till 1945 he held the position of a university professor in Chicago.

During World War II he became involved in social and political activities and developed wide contacts with American socialists. At the beginning of the war he cooperated with emigres of the PPS (the Polish Socialist Party) and, as a representative of this party, was one of the vicepresidents of the Board of the American Union of Liberation of Poland.

\footnotetext{
* Professor, Chair of Statistical Methods, University of Lodz.
} 
In 1941 Oskar Lange wrote an outline of the programme entitled "Economic foundations of democracy in Poland", in which he proved that any democratic programme of economic reconstruction must be based on three fundamental tenets: full employment, just and fair distribution of social income and provisions against concentation of economic power in the hands of both private capital and the state bureaucracy.

In 1943 he initiated a public debate for the sake of Polish - Soviet rerapprochement by publicizing ,An appeal to common sense”. He was also one of the organizers of the so - called Kościuszko League and the American-Polish Labour Council.

In 1944, at the invitation of the Union of Polish Patriots, Lange went to the Soviet Union where he talked to J. Stalin about the fundamental issues of the future Poland. After he had returned to the USA he met with Stanisław Mikołajczyk the then Prime Minister of the emigration government and also briefed the President Roosevelt on his trip.

The years 1945-1947 brought new challenges for Oskar Lange who performed the duties of the ambassador of the People's Republic of Poland in the United States of America, and then since January to till December 1947 the delegate of the United Nations and Security Council. For his merits he was awarded the Commandor's Cross of the Order of Poland's Rebirth by the KRN (National People's Council) on 19 July, 1946.

After serving his term as the ambassador of Poland in the USA and the delegate in the Security Council re returned to Poland. Starting from 1949 he assumed the duties of a professor at the Main School of Planning and Statistics. In the following years (1952-1955) he held the position of the President of the School, and for some part of his term he also headed the Department of Statistics.

Since 1956 he worked as the professor of the Warsaw University and became the head of the Department of Political Economy. He was also a member of the Polish Economic Society where he performed several responsible functions. Starting from 1939 he belonged to the elite circle of Fellows of Econometric Society, and in the final years of WW II he was the editor-in-chief of „Econometrica”. He was elected the full member of the International Statistical Institute as well as the International Econometric Society.

An extensive bibliography of his works includes 848 positions, out of this number 144 were presented in scientific papers or in textbooks in the following fields: political economics, economic politics, sociology, history and cybernetics. Among these publications statistics occupied an 
exceptional position. The fundamental work in the field of statistics is called: „The theory of statistics”, whose first part was published in 1952, and devoted to the problems of description and measuring of statistical communities. The problems related to factors influencing mass processes were to be discussed in the next two parts, however the author did not manage to write them. The second edition of the book, which was published in 1970, included the theory of correlation and linear regression and it was devised by A. Banasiński. Another significant publication in statistics was the article entitled: "Statistical estimation of parameters in Markow process" (1955). His most important work in the area of econometrics and applications of mathematics is titled "An Introduction to Econometrics", (1958) and was translated into numerous languages. The range of scientific interests of Lange was exceptionally wide. His numerous works were of pioneer character - to name but a few; „Optimal decisions" (1964), „An introduction to cybernetics" (1965), and last but not least, „Political economics”.

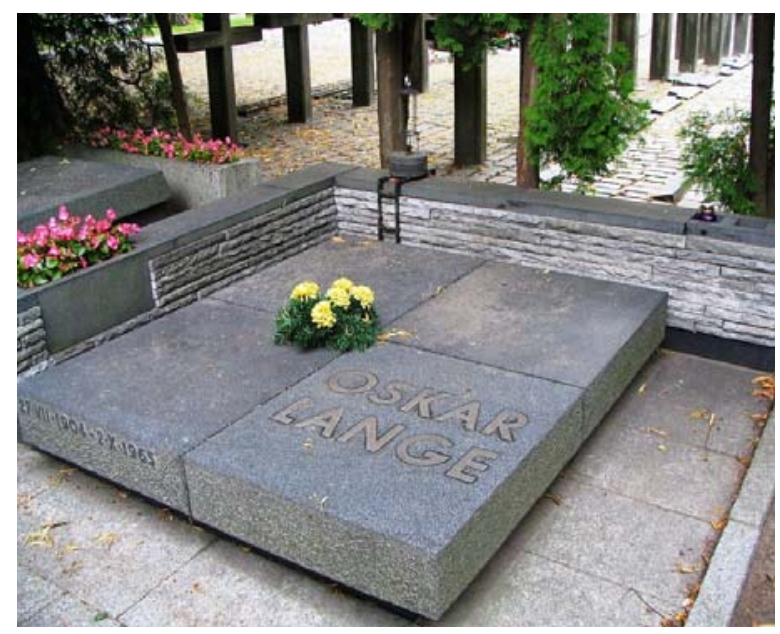

Oskar Lange died on 2 October, 1965 in London, and was buried in the Distinguished Avenue of the Military Cemetery in Warsaw. 
